\title{
Microbiological Analysis of Soil from Onu-Ebonyi Contaminated with Inorganic Fertilizer
}

\author{
Alo M.N., ${ }^{1, *}$ Egbule U.C.C. ${ }^{2}$, Orji J.O. ${ }^{2}$, Aneke C.J ${ }^{3}$ \\ ${ }^{1}$ Department of Biological Sciences, Faculty of Science and Technology, Federal University Ndufu Alike-Ikwo, Ebonyi, Nigeria \\ ${ }^{2}$ Department of Applied Microbiology, Faculty of Biological Sciences, Ebonyi State University, Abakaliki, Ebonyi, Nigeria \\ ${ }^{3}$ Department of Biochemistry, Faculty of Applied Natural Sciences, Enugu State University of Science and Technology, Enugu, \\ Nigeria \\ *Corresponding author: mosesalo44@gmail.com
}

Received April 09, 2013; Revised June 03, 2013; Accepted July 04, 2013

\begin{abstract}
Microbiological analysis of soil from Onu-Ebonyi Izzi local government area of Ebonyi State, Nigeria contaminated with inorganic fertilizer was carried out with a view to determine the effect of the fertilizer on the microbial flora of the soil. Soil samples were analyzed for microbial burden. The result showed that the following organisms were isolated with their frequency of occurrence as follow: Pseudomonas species (33.3\%) and Aspergillus species (54.4\%) had the highest frequency of occurrence in the whole sample batches, while Streptococcus species had 6.0\% and Geotrichum species (5.3\%) had the least. Other predominant microorganism isolated include: Bacillus species, Staphylococcus species and Vibrio species, Escherichia species, Rhizopus species, Mucor species and Fusarium species. From the results, it could be concluded that the soil was contaminated and this could affect adversely the fertility of the soil.
\end{abstract}

Keywords: soil, bacteria, fungi, inorganic fertilizer, Onu-Ebonyi

Cite This Article: Alo M.N., Egbule U.C.C., Orji, J.O., and Aneke C.J, "Microbiological Analysis of Soil from Onu-Ebonyi Contaminated with Inorganic Fertilizer." American Journal of Infectious Diseases and Microbiology 1, no. 4 (2013): 70-74. doi: 10.12691/ajidm-1-4-3.

\section{Introduction}

Inorganic fertilizer is a fertilizer of synthetic origin (other than liming materials) which contains all that is added to a soil to supply one or more plant nutrients essential to the growth of plants [1,2]. A recent assessment found that about 40 to $60 \%$ of crop yields are attributable to commercial fertilizer use [1]. But despite the beneficial effects in of inorganic fertilizer in improving biodiversity (soil site), long-term productivity of soil and large depository for excess carbon dioxide will also cause enormous detrimental effect on both man and animals inhabiting the soil environment especially in selective distribution of microorganisms when excessively applied, when applied inappropriately without considering the soil texture/composition [3].

The soil microorganisms are sensitive to changes in the surrounding soil [4] and have been shown that the microbial population changes after fertilization [5]. Fertilizer can directly stimulate the growth of microbial populations as a whole by supplying nutrients and may affect the composition of individual microbial communities in the soil and also nearby water bodies hence posing detrimental effect on the terrestrial and aquatic environment [6]. The impact of industrial wastes and chemical contaminants on soil has been extensively studied within and outside Nigeria [7]. This is because environmental pollution caused by excessive soil erosion and the associated transport of sediment, chemical fertilizer and pesticide to the surface and ground water and social problems throughout the world $[8,9]$.

Thus the fertilizer and chemical plant at Onu-Ebonyi in Izzi Local Government Area of Ebonyi State is one among the country blending fertilizer companies. Its raw materials constitute already produced materials such as lime stone (filters), varying percentage of urea, muriate of potash (MOP) and diamonium phosphate for synthesis/production of various forms of inorganic fertilizers such as NPK, urea etc. But these blending and production processes generate and release enormous waste containing nitrogen and phosphorous/ potassium into the terrestrial and aquatic environments or habitats. Thus the accumulation of the waste materials could generate toxic and hazardous effect on both human and other inhabitants of the environment [7] effects of industrial waste and chemical contaminant such as fertilizer have contributed to environmental pollution caused by transportation of fertilizer, chemicals, and pesticide sediments/soil erosion all over the world [8].

Because of the detrimental effect of industrial waste such as fertilizer companies generated waste, U.S.A. Environmental Impact Assessment was established firstly in 1969 to identify, predict the impact of hazardous waste on the environment/human health and on the general well seeing of legislative proposals, programmes, projects etc for formulation of governmental policies that guild these 
industries [10]. Hence the purpose of environmental assessment and management is ultimately the maintenance of biological integrity and also physicochemical parameters. Therefore, this present work is design to ascertain the microbiological analysis of soil from OnuEbonyi contaminated with inorganic fertilizer.

\section{Materials and Methods}

\subsection{Study Area}

This study was conducted within the Onu-Ebonyi Fertilizer and Chemical Plant Company premises, in Izzi Local Government Area of Ebonyi state. The study area is located between Latitude $06^{\circ} 4^{\prime} \mathrm{N}$ and longitude $08^{\circ} \mathrm{C} 5^{\prime} \mathrm{E}$ and rainfall pattern is bimodal (April-July), SeptemberNovember with a short spell sometimes in August. The annual rainfall is between $1000 \mathrm{~mm}-1500 \mathrm{~mm}$. The vegetation of the area is predominantly derived Savannah. The mean annual temperature is about $24^{\circ} \mathrm{C}$ and the relative humidity is between $60-80 \%$ [11].

\subsection{Sample Collection}

The samples were subjected to microbiological analysis within 24 hours of collection. One gram of the soil samples was measured and dissolved in $9 \mathrm{ml}$ of sterile distilled water and was tenfold serially diluted. The tenfold serial dilution of the sample was prepared using normal saline as the diluent factor $[12,13]$.

\subsection{Microbiological Analysis}

A $0.1 \mathrm{ml}$ aliquot of ten-fold serial dilution of the sample was inoculated onto the plates, with pour plate method. The plates were incubated at room temperature for 18-24 hours. Observations were made for development of colonies [14]. The visible colonies on the plates were counted (30-300) and recorded, based on the dilution factor used, $10^{-6}$ was used.

\section{Number of organisms}

$$
=\frac{\text { Number of colonies }}{0.1} \times \frac{\text { Dilution factor }}{1}
$$

The observed growths were sub-cultured to obtain pure isolates. This was achieved by inoculating the individual colonies in a nutrient agar slant and incubated between 35$37^{\circ} \mathrm{C}$ for 24 hours. The isolates were subsequently stored at $4^{\circ} \mathrm{C}$ in the refrigerator according to Onyeagba [13].

Identification of the test isolates was done based on morphological and biochemical tests: Sugar fermentation test (glucose, fructose and lactose), Voges Proskauer test, catalase test, coagulase test, oxidase test and indole test, including Gram staining reaction and motility tests were carried out for proper characterization of bacterial isolates according to Ezeonu [15].

\section{Results and Discussion}

In this study, the bacterial isolates from the contaminated inorganic fertilizer sites encompass Pseudomonas species, Bacillus species, Staphylococcus aureus, Vibrio specie, Streptococcus species and Escherichia species as in Table 1. This is similar to the work of Hashem [16], who isolated Bacillus, Corynebacterium, Listeria, Staphylococcus and Pseudomonas species in different Saudi Arabian soil. However, Corynebacterium and spp. Listeria, were not isolated in this study. This could be as a result of differences in techniques used.

Table 1. Characteristics of the bacteria isolates from inorganic fertilizer enriched soil

\begin{tabular}{|c|c|c|c|c|c|c|c|c|c|c|c|}
\hline \multicolumn{2}{|c|}{ Morphological characterization } & \multirow{2}{*}{$\begin{array}{c}\text { Gram } \\
\text { staining }\end{array}$} & \multirow{2}{*}{$\begin{array}{c}\text { Catalase } \\
\text { Test }\end{array}$} & \multirow{2}{*}{$\begin{array}{l}\text { Oxidase } \\
\text { Test }\end{array}$} & \multirow{2}{*}{$\begin{array}{c}\text { Indole } \\
\text { Test }\end{array}$} & \multirow{2}{*}{$\begin{array}{c}\text { Voges } \\
\text { Proskauer }\end{array}$} & \multirow{2}{*}{$\begin{array}{l}\text { Motility } \\
\text { Test }\end{array}$} & \multicolumn{3}{|c|}{ Sugar Fermentation Test } & \multirow{2}{*}{$\begin{array}{l}\text { Suspected } \\
\text { Organisms }\end{array}$} \\
\hline Colour & Consistency/Texture & & & & & & & Glucose & Lactose & Fructose & \\
\hline $\begin{array}{c}\text { Light } \\
\text { yellow }\end{array}$ & Slightly raised & - & + & + & - & - & - & + & - & - & $\begin{array}{c}\text { Pseudomonas } \\
\text { species }\end{array}$ \\
\hline Grayish & Small round colony & + & - & + & - & - & - & + & - & - & Bacillus species \\
\hline Creamy & $\begin{array}{c}\text { Raised/ } \\
\text { smooth edge }\end{array}$ & + & + & - & - & - & - & + & - & - & $\begin{array}{c}\text { Staphylococcus } \\
\text { species }\end{array}$ \\
\hline Creamy & Flat colonies & - & + & + & - & - & + & + & - & - & Vibrio species \\
\hline $\begin{array}{l}\text { White } \\
\text { mucoid }\end{array}$ & Rough surface & + & - & - & - & - & - & + & - & - & $\begin{array}{c}\text { Streptococcus } \\
\text { species }\end{array}$ \\
\hline Greenish & Rough surface & - & + & - & + & - & - & + & + & - & $\begin{array}{c}\text { Escherichia } \\
\text { species }\end{array}$ \\
\hline
\end{tabular}

The type of bacteria present in terrestrial environment is often dependent on the nature of nutrient available and the competency of the microbial population to withstand the pressure (stress imposed on them by the pollutants) [17]. Their detection stems from their ability to survive and function under stress $[17,18]$.

Pseudomonas species had the highest frequency of $31.4 \%$ from the sample groups (A, B and C), followed by Escherichia species (17.6\%) and Bacillus species (15.7\%) and Staphylococcus species (15.7\%), while Streptococcus species had the least frequency of $7.8 \%$. High frequency of Pseudomonas species has been isolated in many polluted environment as a result of its physiological and metabolic versatility [19] and its bioaccumulation activities on copper $(\mathrm{Cu})$, lead $(\mathrm{Pb})$ and other heavy metal ions [20]. Also, Bacillus species have been isolated from soil samples collected from Aramco Gulf Operations Company Al-khafji, Saudi Arabia [21]. The isolates of
Bacillus species in this work is in consistent with the report of Okey [22]. Johnson and Eaton [23] who stated that Bacillus species survive in adverse environment by the formation of spores. The detection of Escherichia species could be as a result of human activities within the environment such as defecation as observed in this study.

The sample group $\mathrm{D}$, which is obtained from the premises outside the fertilizer contaminated site showed more bacterial and fungal isolates when compared to the sites contaminated with the inorganic fertilizer. However, microbial population increases as one moves away from the site of production (disposal site) an observation that conforms to the work of Dobler [24], who reported that substrate metabolism (utilization) by microbes' increases with distance away from the point of heavy pollution. Soil microbial biomass, which plays an important role in the nutrients cycling and ecosystem suitability, has been found to be sensitive to increase heavy metal 
concentration in soils $[25,26]$. However, an increasing body of evidence those microorganisms are far more sensitive to heavy metals stress than soil animals or plants growing on the same soil [25]. Thus, measure of the fate of microbial community following the initiation of reclamation efforts or the microbial responding would therefore, serve as an indicator of restoration progress [27] and may give insight into a potential ways to accelerate restoration.

The fungal isolates were Aspergillus species, Rhizopus species, Mucor species Geotrichum species and Fusarium species as in Table 2.

Table 2. Morphological and microscopic feature of fungi isolated from inorganic fertilizer enriched soil

\begin{tabular}{|c|c|c|}
\hline Morphological Characteristics & Microscopic Examination & Suspected Organisms \\
\hline $\begin{array}{c}\text { Velvety filamentous white growth that sporulate } \\
\text { black powdery spores }\end{array}$ & $\begin{array}{c}\text { Long septate hyphae with conidiophore bearing brown spores and } \\
\text { phialide at its apex }\end{array}$ & Aspergillus species \\
\hline $\begin{array}{c}\text { Long hyphal growth which sporulated within two } \\
\text { days to turn to black spore }\end{array}$ & Non-septate, branched mycellium with round shaped sporangia & Rhizopus species \\
\hline $\begin{array}{c}\text { White and wooly aerial growth that darkens as it } \\
\text { sporulate }\end{array}$ & $\begin{array}{c}\text { Non-septate hyohae with straight sporangiophore with many } \\
\text { spherical spores. }\end{array}$ & Mucor species \\
\hline $\begin{array}{c}\text { Whitish smooth circular and raised colony or } \\
\text { growth. }\end{array}$ & Presence of arthrospore spores with rounded end & Geotrichum species \\
\hline $\begin{array}{c}\text { Pink fluffy and spreading colonies which is creamy } \\
\text { around edges }\end{array}$ & Septate hyphae with sickle chlamydospores at the hyphae & Fusarium species \\
\hline
\end{tabular}

The bacterial isolates for the group A, B, and C were predominantly Pseudomonas species with the highest frequency (31.4\%) followed by Escherichia species (17.6\%) and Bacillus species (15.7\%), while Streptococcus species (7.8\%) showed the least frequency as in Table 3. In the same vein, Pseudomonas species was the predominant bacterial isolate in group $\mathrm{D}$ with the highest frequency (21.2\%) followed by Escherichia species (17.7\%) and Bacillus species (16.8\%), while Staphylococcus species (13.3\%) showed the least frequency as also shown Table 3.

The frequency of occurrence of the bacterial isolates showed that out of the six bacterial isolates, Pseudomonas species (33.3\%) has the highest frequency in sample group

A, followed by Bacillus species (16.7\%) and Escherichia species (16.7\%), while Staphylococcus species, Vibrio species and Streptococcus species had the least frequency of $11.1 \%$ each (Figure 1). Pseudomonas species also recorded the highest frequency with $30.0 \%$ in sample batch B, followed by Bacillus species (25.0\%), Staphylococcus species (20.0\%), Escherichia species (20.0\%), Streptococcus species had frequency of 5.0\%, while Vibrio species had the least frequency of $0.0 \%$. In sample group C, Pseudomonas species and Vibrio species had the highest frequency of $30.8 \%$ each, followed by Staphylococcus species and Escherichia species with $15.4 \%$ each, Streptococcus species had $7.6 \%$ while Bacillus species had the least frequency of $0.0 \%$ (Table 3).

Table 3. Percentage frequency of bacterial isolates from each sample (group A, B, C and D)

\begin{tabular}{|c|c|c|c|c|}
\hline Bacterial Isolates & $\begin{array}{c}\text { (50 Sample) Group A } \\
(\%)\end{array}$ & $\begin{array}{c}\text { (50 Sample) Group } \\
\text { B (\%) }\end{array}$ & $\begin{array}{c}\text { (50 Sample) } \\
\text { Group C (\%) }\end{array}$ & $\begin{array}{c}\text { (50 Sample) } \\
\text { Group D (\%) }\end{array}$ \\
\hline Pseudomonas species & $6(33.3 \%)$ & $6(30.0 \%)$ & $4(30.8 \%)$ & $40(31.4 \%)$ \\
\hline Bacillus species & $3(16.7 \%)$ & $5(25.0 \%)$ & - & $24(21.2 \%)$ \\
\hline $\begin{array}{c}\text { Staphylococcus } \\
\text { species }\end{array}$ & $2(11.1 \%)$ & $4(20.0 \%)$ & $2(15.4 \%)$ & $23(15.7 \%)$ \\
\hline Vibrio species & $2(11.1 \%)$ & - & $4(30.8 \%)$ & $24(11.8 \%)$ \\
\hline Streptococcus species & $2(11.1 \%)$ & $1(5.0 \%)$ & $1(7.6 \%)$ & $21(7.8 \%)$ \\
\hline Escherichia species & $3(16.7 \%)$ & $4(20.0 \%)$ & $2(15.4 \%)$ & $29(17.6 \%)$ \\
\hline Total & 18 & 20 & 13 & $17(15.9 \%)$ \\
\hline
\end{tabular}

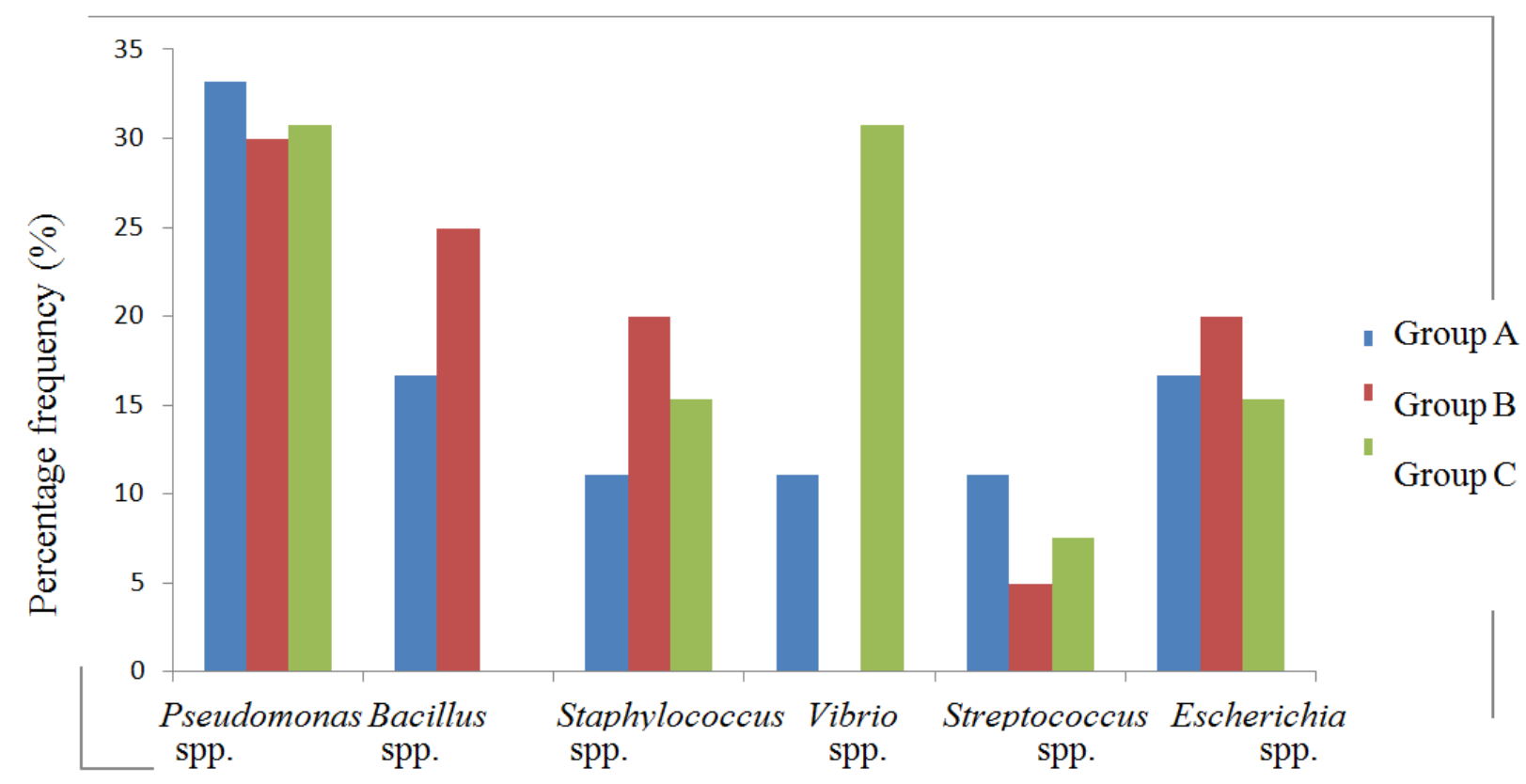

Figure 1. Percentage frequency of bacterial isolates from each sample (group A, B and C) 
Moreover, the fungal isolates were majorly Aspergillus species with the highest frequency of $42.2 \%$ followed by Rhizopus species (26.7\%), Mucor species (16.7\%), Geotrichum species (12.2\%), while Fusarium species (2.2\%) recorded the least frequency as in Figure 2. Aspergillus species was the predominant fungal isolate in group D with the highest frequency (31.2\%) followed by Rhizopus species (21.2\%) and Geotrichum species (17.2\%), while Mucor species and Fusarium species showed the least frequency of $15.2 \%$ as shown in Figure 2.

The frequency of occurrence of the fungal isolates has showed that out of the five fungal isolates, Aspergillus species (38.2\%) has the highest frequency in sample group A, followed by Rizopus species (23.6\%), Geotrichum species (20.0\%) and Mucor species (18.2\%), while Fusarium species had the least frequency of $0.0 \%$. Aspergillus species also recorded the highest frequency with $44.0 \%$ in sample group B, followed by Rizopus species (32.0\%), Mucor species (16.0\%) and Fusarium species (8.0\%), while Geotrichum species had the least frequency of $0.0 \%$. In the same vein, Aspergillus species had the highest frequency of $60.0 \%$ in sample group C, followed by Rizopus species (30.0\%) and Mucor species (10.0\%), while Geotrichum species and Fusarium species showed the least frequency of $0.0 \%$ each (Figure 2 ). The higher the fertilizer contamination of the soil the lower the microbial population.

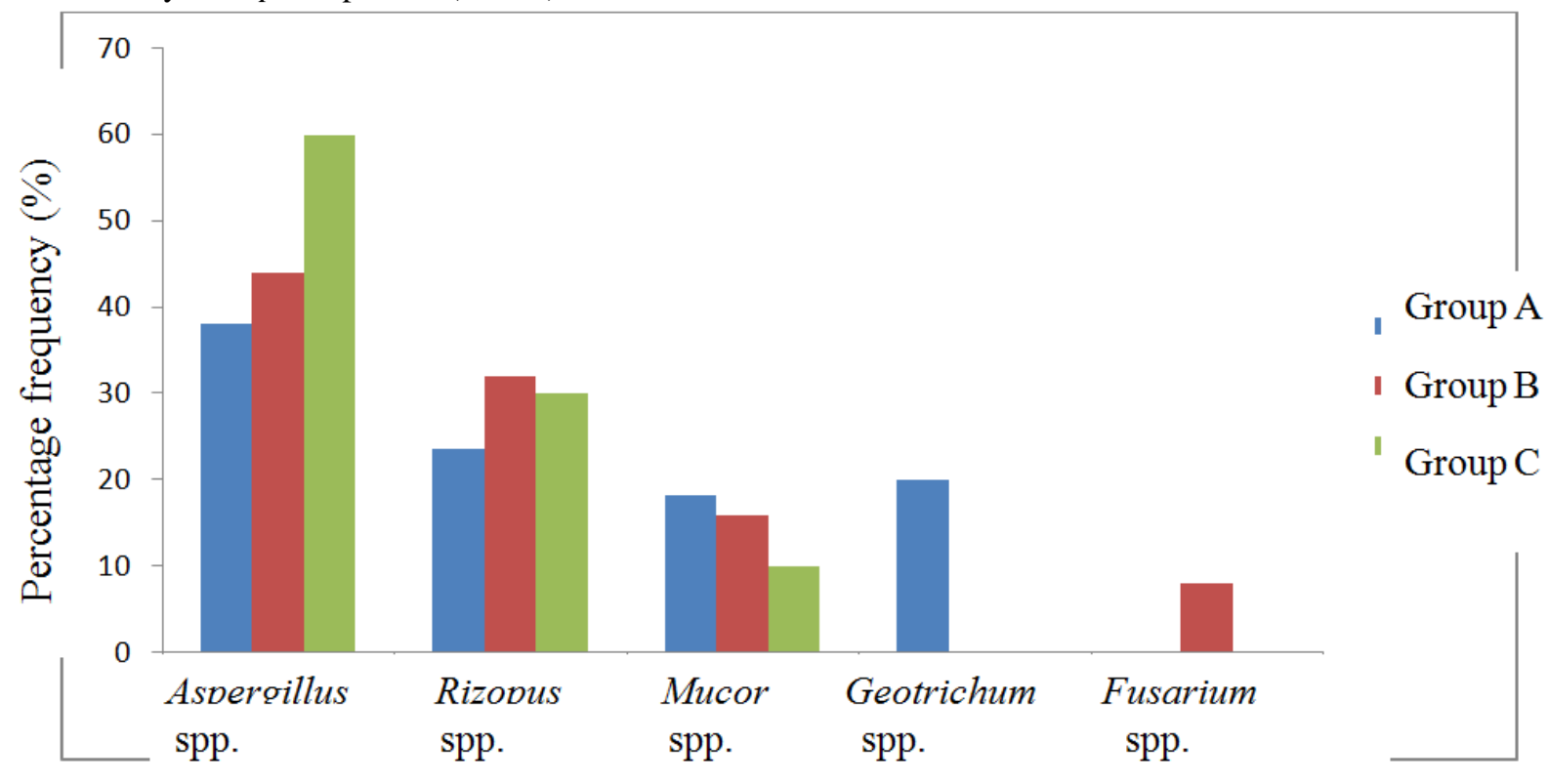

Figure 2. Percentage frequency of fungal isolates from each sample (group A, B, C)

The levels of metals found in the environment do not pose a concern for immediate (acute) health effect; however, constant exposure over the years to even relatively low levels of many metals can increase the risk of the long term (chronic) health problem [28]. Metals can build up in the body and tend to remain there for years. Their effect can be very hard to detect and/or not show up for many years. Children and the unborn are especially vulnerable to the effect of lead (Pb), Mercury (Hg) and arsenic compounds. Cadmium (Cd) attacks the kidney and may result in kidney failure later in life [23,29]. Excessive ammonia-nitrogen, urea, nitrate and other physicochemical parameters in the environment cause an inevitable consequence as underground water nitrate levels increases. The water bodies such as streams and ponds used by residents within the Onu-Ebonyi fertilizer complex could lead to respiratory problems and other health hazards. The dilution effect that occur in rainy season and the attendant leaching of substances like phosphorus and other heavy metals to underground water and also to nearby source of water like stream, ponds by erosion is likely to cause negative effect to aquatic organisms and health hazard to humans.

\section{Conclusion}

The result of this work has clearly shown that soil sample become eminent as the habitat affects man extensively and anything affecting this habitat (soil) affects human food, health and general well being.

The result of this work has also revealed that high level of some chemicals such as phosphorus, nitrogen, potash, boron and urea affects the quality of soil especially around the premises of the fertilizer plant and also the microbial flora which invariably will affect the soil fertility. This could also affect the health of the people that are constantly exposed to it or use the water contaminated by inorganic fertilizer.

This work is very useful for efficient pollution supervising and for drawing pollution control strategy for soil within Onu-Ebonyi fertilizer complex and also calls for the management of waste generated that may pose health associated risks and hazards.

\section{References}

[1] Stewart, W.M., Dibb, D.W., Johnston, A.E., Smyth, T.J. The contribution of commercial fertilizer nutrients to food production. Agronomy Journal, 97: 1-6, 2005.

[2] Abram, A., Forster, D.L. A primer on ammonia, nitrogen fertilizers, and natural gas markets. Department of Agricultural, Environmental, and Development Economics, Ohio State University. P. 38, 2005.

[3] Lah, R. Soil carbon sequestration impact on global climate change and food security. Science Journal, 304(5677): 623-627, 2004.

[4] Schinner, F., Sonnletner, R. Bodenokologie: Mikrobiologic und Bodenenzymatik. Springer Verlag, New York. P. 46, 1996. 
[5] Hyman, M.R., Kim, C.Y., Arp, D.J. Inhibition of ammonia monooxygenase in Nitromonas europaea by carbon disulfide. J. Bacteriol., 172: 4775-4782, 1990.

[6] Khonje, D.J., Varsa, E.C., Klubek, B. The acidulation effects of nitrogenous fertilizers on selected chemical and microbiological properties of soil. Commun. Soil Sci. Plant Anal., 20: 1377-1395, 1989.

[7] Godson, R.E.E., Mynepahs, K.S.C. The soil quality of new chemical fertilizer industry, Port Harcourt. Division of environmental health, University of Ibadan. PP. 7-37, 2004.

[8] Parrett, J.F., Papendick, R.I., Horinck, S.B., Meyer, R.E. Soil quality attribute and relationship to alternative and sustainable agriculture. American Journal of Alternative Agriculture, 7: 5-11, 1992.

[9] Reganold, J.P., Papendick, R.I., Parr, J.F. Sustainable agriculture. Scientific American, 262 (6): 112-120, 1990.

[10] Glasson, J., Thervel, R., Chadrock, A. Introduction to environmental impact assessment, $2^{\text {nd }}$ edition Mc-Graw hill, USA. PP. 3-6, 1999.

[11] Ofomata, G.E.K. Nigeria in Maps (Eastern States). Ofomata Edition Ethiopia Publisher, Benin City. PP. 45-46, 1975

[12] Nduka, O. Environemental microbiology of aquatic and waste systems, $2^{\text {nd }}$ edition. Springer Dordredd Heildelberg, London New York. PP. 157-168, 2011.

[13] Onyeagba, R.A. Laboratory guide for microbiology. $1^{\text {st }}$ edition. Crystal Publishers. No. 46 Owerri Road Okigwe, Imo State Nigeria. PP. 95-117, 2004.

[14] Cheesbrough, M. District laboratory practice in tropical countries, part 2. Cambridge University Press, Cambridge, UK. PP. 137-150, 2006.

[15] Ezeonu, I.M., Okafor, J.I., Ogbonna, J.C. Laboratory exercises in microbiology. A practical manual for students of tertiary institution. $1^{\text {st }}$ edition. Ephrata Printing and Publishing Company, N0. 12 Orba Road, Nsukka, Nigeria. PP. 67-69, 2011.

[16] Hashem, A.R. Influence of crude oil contamination on the chemical and microbiological aspects of Saudi Arabian soil. J. King Saud. Univ., 8(1): 11-18, 1996.

[17] Barkay, T., Pritchard, H. Adaptation of aquatic microbial communities to pollutant stress. Microbiol. Sci., 5: 165-669, 1988.
[18] Kivisaar, M. Stationary mutagenesis: Mechanisms that accelerate adaptation of microbial population under environmental stress. Environ. Microbial., 5 (10): 814-827, 2003.

[19] Obahiagbon, K.O., Erhabor, I. Biodegradation of refinery wastewater using Pseudomonas aeruginosa and Fusarium. National Journal of Information Sharing and initiative, 1: 77-111, 2002.

[20] Lovely, D.R., Philip, E.J.P., Gorby, Y.A., Linda, E.R. Microbial reduction of uranium. Nature, 350: 413-416, 1991.

[21] Al-Yemeni, M.N., Hashem, A.R. Heavy Metals and Microbial Analysis of Soil Samples Collected from Aramco Gulf Operations Company Al-khafji, (AGOC) Saudi Arabia. Saudi Journal of Biological Sciences, 13(2): 129-133, 2006.

[22] Okey, C. Ecology and genomics of Bacillus subtilis. Trends in Microbiology, 16 (6): 268-274, 2003.

[23] Johnson, M.S., Eaton, J.W. Environmental contamination through residual trace metals dispersed from dielectric lead-zinc mine. Journal of Envron. Qual., 9 (2): 175-179, 1980

[24] Dobler, R., Burri, P., Gruiz, K., Brandl, H., Bachofen, R. Variability in microbial population in soil highly polluted with heavy metals in the basis of substrate utilization pattern analysis. J. soils and Sed., 1 (3): 151-158, 2001.

[25] Giller, K.E., Witter, E., McGrath, S.P. Toxicity of heavy metals to microorganism and microbial processes in agricultural soil: A review. Journal of Soil Biology and Biochemistry, 30: 1389-1414, 1998.

[26] Huang, C., Khan, R.S. Effect of cadmium, lead and their interaction on the size of microbial biomass in a red soil. Journal of Soil Environment, 1: 227-236, 1998.

[27] Harris, J.A., Benthan, H., Birch, P. Soil microbial community provide index to progress direction of restoration. Journal of Restoration Management Notes, 9: 133-135, 1991.

[28] Depue, I. New Jersey zinc/mobile chemical site. Sample Result Fact Sheet, 1: 38-41, 1992.

[29] Pockock, S.J., Smith, M., Baghurst, P. Environmental lead and children's intelligence: A systematic review of the epidemiological evidence. Brit. Med. J., 309: 1189-1197, 1994. 